\title{
Asperindoles A-D and a $p$-Terphenyl Derivative from the Ascidian-Derived Fungus Aspergillus sp. KMM 4676
}

\author{
Elena V. Ivanets ${ }^{1}$, Anton N. Yurchenko ${ }^{1, *}$, Olga F. Smetanina ${ }^{1}$, Anton B. Rasin ${ }^{1}$, \\ Olesya I. Zhuravlevaa ${ }^{1,2}$, Mikhail V. Pivkin ${ }^{1}$, Roman S. Popov ${ }^{1}$, Gunhild von Amsberg ${ }^{3}$, \\ Shamil Sh. Afiyatullov ${ }^{1}$ and Sergey A. Dyshlovoy ${ }^{1,2,3}$ (i) \\ 1 G.B. Elyakov Pacific Institute of Bioorganic Chemistry, Far Eastern Branch of the Russian Academy of \\ Sciences, Prospect 100-letiya Vladivostoka, 159, Vladivostok 690022, Russia; ev.ivanets@yandex.ru (E.V.I.); \\ smetof@rambler.ru (O.F.S.); abrus_54@mail.ru (A.B.R.); zhuravleva.oi@dvfu.ru (O.I.Z.); \\ oid27@mail.ru (M.V.P.); prs_90@mail.ru (R.S.P.); afiyat@piboc.dvo.ru (S.S.A.); dyshlovoy@gmail.com (S.A.D.) \\ 2 School of Natural Science, Far Eastern Federal University, Sukhanova St., 8, Vladivostok 690000, Russia \\ 3 Laboratory of Experimental Oncology, Department of Oncology, Hematology and Bone Marrow \\ Transplantation with Section Pneumology, Hubertus Wald-Tumorzentrum, University Medical Center \\ Hamburg-Eppendorf, 20246 Hamburg, Germany; g.von-amsberg@uke.de \\ * Correspondence: yurchant@ya.ru; Tel.: +7-423-231-1168
}

Received: 7 June 2018; Accepted: 3 July 2018; Published: 9 July 2018

\begin{abstract}
Four new indole-diterpene alkaloids asperindoles A-D (1-4) and the known $p$-terphenyl derivative 3"-hydroxyterphenyllin (5) were isolated from the marine-derived strain of the fungus Aspergillus sp., associated with an unidentified colonial ascidian. The structures of 1-5 were established by 2D NMR and HRESIMS data. The absolute configurations of all stereocenters of 1-4 were determined by the combination of ROESY data, coupling constants analysis, and biogenetic considerations. Asperindoles C and D contain a 2-hydroxyisobutyric acid (2-HIBA) residue, rarely found in natural compounds. Asperindole A exhibits cytotoxic activity against hormone therapy-resistant PC-3 and 22Rv1, as well as hormone therapy-sensitive human prostate cancer cells, and induces apoptosis in these cells at low-micromolar concentrations.
\end{abstract}

Keywords: marine-derived fungi; secondary metabolites; indole-diterpenoids; cytotoxicity

\section{Introduction}

Marine fungi are promising and prolific sources of new biological active compounds. Fungi of the genus Aspergillus, section Candidi (A. candidus, A. campestris, A. taichungensis, A. tritici), are known to produce several types of $p$-terphenyl derivatives, such as terphenyllins (terphenyllin [1], 3-hydroxyterphenyllin [2], terprenins [3]) and candidusins (candidusins A-C [4], prenylcandidusins A-C [5]), and a number of flavonoid derivatives (e.g., chlorflavonin [6], chlorflavonin A [7]). These compounds exhibit antioxidant [8,9], cytotoxic [5,9,10], antimicrobial [9], and immunosuppressive activities [9]. Recently, several indole and pyrrolidine alkaloids unusual for this fungal group were isolated from a Thai sponge-derived $A$. candidus strain [11].

Indole-diterpene alkaloids are widely represented among the fungal metabolites. These compounds have been isolated from fungi of the genera Claviceps, Acremonium, Eupenicillium, Penicillium, and Aspergillus (including Emericella striata). Most natural indole-diterpenes have an invariable framework (Figure 1). Usually, C-7, C-13, and C-27 are oxidized. The oxygenation of C-27 is often followed by the formation of an ether bridge between C-27 and C-7 with inversion of the stereoconfiguration at C-7 [12]. Interestingly, some fungi produce metabolites with relatively 
rare features in the classical indole-diterpene backbone. For example, Acremonium lolii produces indoles diprenylated at C-20 and C-21, together with oxygenated derivatives [13]. Alkaloids with a 1,3-dioxane moiety joined at C-9 and C-10 with the F-ring from A. lolii have also been reported [14,15]. Many of such compounds showed tremorgenic [16], cytotoxic [17,18], and antiinsectan [19] activities, and some of them are antagonists of cannabinoid receptors [20].

Based on promising screening results in search of producers of biologically active compounds, the marine-derived fungus Aspergillus sp. KMM 4676, which is associated with an unidentified colonial ascidian (from the Shikotan Island in the Pacific Ocean), was selected for further studies. During earlier examinations of this fungal strain, five known $p$-terphenyls and one known flavonoid were isolated [21]. Herein, we describe the results of subsequent comprehensive chemical and bioactivity investigations of the extracts of strain KMM 4676, leading to the characterization of four new natural compounds.

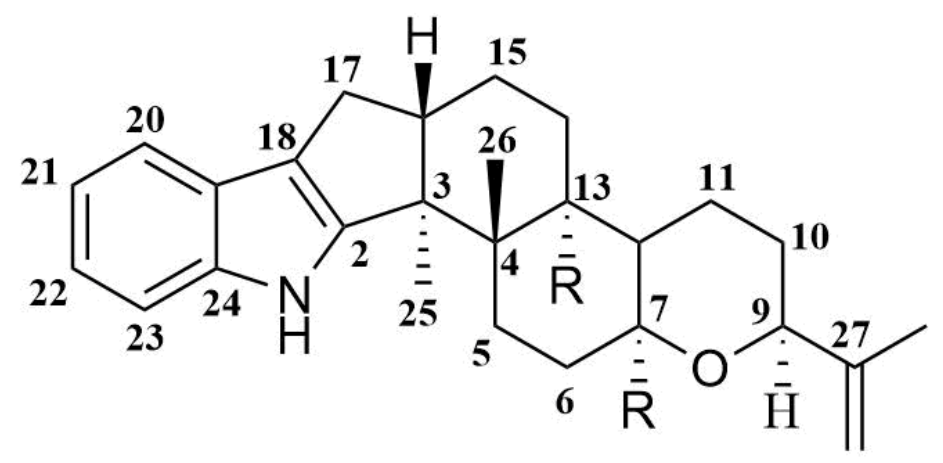

Figure 1. Usual framework of indole-diterpenes.

\section{Results}

The HRESIMS spectrum of 1 exhibited a pseudo-molecular peak at $m / z 526.1980[\mathrm{M}+\mathrm{H}]^{+}$, showing the characteristic isotope pattern with one chlorine atom, therefore establishing its molecular formula as $\mathrm{C}_{29} \mathrm{H}_{32} \mathrm{NO}_{6} \mathrm{Cl}$, which was supported by the ${ }^{13} \mathrm{C}$ NMR spectrum.

Inspection of the ${ }^{1} \mathrm{H}$ and ${ }^{13} \mathrm{C}$ NMR data (Table 1, Figures S1-S2) of 1 revealed the presence of three quaternary methyls $\left(\delta_{\mathrm{C}} 16.1,17.0,23.4 ; \delta_{\mathrm{H}} 1.02,1.21,1.31\right)$, one acetate methyl $\left(\delta_{\mathrm{C}} 21.8, \delta_{\mathrm{H}} 2.07\right)$, six methylene $s p^{3}\left(\delta_{\mathrm{C}} 20.8,26.3,26.9,30.0,31.5,64.8 ; \delta_{\mathrm{H}} 1.66,1.77,1.91,1.93,2.00,2.11,2.30,2.40,2.55\right.$, $2.60,3.67,4.04)$, two methine $s p^{3}\left(\delta_{\mathrm{C}} 48.3,78.3, \delta_{\mathrm{H}} 2.72,4.74\right)$, four methine $s p^{2}\left(\delta_{\mathrm{C}} 111.3,118.6,118.7\right.$, $\left.119.9 ; \delta_{\mathrm{H}} 6.11,6.91,7.26,7.27\right)$, three quaternary oxygen-bearing $s p^{3}\left(\delta_{\mathrm{C}} 75.0,77.0,93.6\right)$, two quaternary $s p^{3}\left(\delta_{C} 38.5,51.4\right)$, and eight quaternary $s p^{2}\left(\delta_{C} 115.0,123.3,123.7,140.2,154.0,159.1,170.2,195.9\right)$ carbons, as well as a $\mathrm{NH}$ singlet $\left(\delta_{\mathrm{H}} 10.73\right)$ and an $\mathrm{OH}$ singlet $\left(\delta_{\mathrm{H}} 5.10\right)$.

The ${ }^{1} \mathrm{H}$ and ${ }^{13} \mathrm{C}$ NMR spectra of $\mathbf{1}$ (Table 1 ) resembled those of paspalinine [16], suggesting that $\mathbf{1}$ has an indole-diterpene core similar to that of paspalinine. However, the differences in chemical shift values of $\mathrm{C}-19\left(\delta_{\mathrm{C}} 123.3\right)$ and C-22 $\left(\delta_{\mathrm{C}} 123.7\right)$ of 1 from the corresponding carbons in paspalinine [16]; the HMBC correlations (Figure 2, Figure S5) from H-20 $\left(\delta_{\mathrm{H}} 7.26\right)$ to $\mathrm{C}-18\left(\delta_{\mathrm{C}} 115.0\right)$ and C-22, from H-21 $\left(\delta_{\mathrm{H}} 7.26\right)$ to $\mathrm{C}-19$ and $\mathrm{C}-23\left(\delta_{\mathrm{C}} 111.3\right)$, and from H-23 $\left(\delta_{\mathrm{H}} 7.26\right)$ to $\mathrm{C}-19$ and $\mathrm{C}-21\left(\delta_{\mathrm{C}} 118.7\right)$; and the coupling constants $J_{\mathrm{H} 20-\mathrm{H} 21}(8.5 \mathrm{~Hz})$ and $J_{\mathrm{H} 21-\mathrm{H} 23}(2.1 \mathrm{~Hz})$ suggested the presence of a chlorine atom on C-22 of 1 . 
Table 1. ${ }^{13} \mathrm{C}$ NMR data $\left(125 \mathrm{MHz}, \delta\right.$ in ppm, DMSO- $\left.d_{6}\right)$ for asperindoles A-D (1-4).

\begin{tabular}{|c|c|c|c|c|}
\hline Position & 1 & 2 & 3 & 4 \\
\hline 2 & 154.0, C & $152.8, \mathrm{C}$ & 154.1, C & $152.8, \mathrm{C}$ \\
\hline 3 & $51.4, \mathrm{C}$ & $51.2, \mathrm{C}$ & $51.4, \mathrm{C}$ & $51.2, \mathrm{C}$ \\
\hline 4 & $38.5, \mathrm{C}$ & $38.6, \mathrm{C}$ & $38.5, \mathrm{C}$ & 38.6, C \\
\hline 5 & $26.3, \mathrm{CH}_{2}$ & $26.2, \mathrm{CH}_{2}$ & 26.3, $\mathrm{CH}_{2}$ & $26.2, \mathrm{CH}_{2}$ \\
\hline 6 & $30.0, \mathrm{CH}_{2}$ & $30.1, \mathrm{CH}_{2}$ & $30.0, \mathrm{CH}_{2}$ & $30.0, \mathrm{CH}_{2}$ \\
\hline 7 & $93.6, \mathrm{C}$ & $93.6, \mathrm{C}$ & $93.6, \mathrm{C}$ & $93.5, \mathrm{C}$ \\
\hline 9 & $78.3, \mathrm{CH}$ & $78.3, \mathrm{CH}$ & $78.3, \mathrm{CH}$ & $78.6, \mathrm{CH}$ \\
\hline 10 & $195.9, \mathrm{C}$ & $195.9, \mathrm{C}$ & $195.9, \mathrm{C}$ & $195.7, \mathrm{C}$ \\
\hline 11 & $119.9, \mathrm{CH}$ & $119.9, \mathrm{CH}$ & $119.9, \mathrm{CH}$ & $119.8, \mathrm{CH}$ \\
\hline 12 & 159.1, C & $159.2, \mathrm{C}$ & $159.1, \mathrm{C}$ & $159.2, \mathrm{C}$ \\
\hline 13 & $77.0, \mathrm{C}$ & $77.0, \mathrm{C}$ & $77.0, \mathrm{C}$ & 77.0, C \\
\hline 14 & $31.5, \mathrm{CH}_{2}$ & $31.6, \mathrm{CH}_{2}$ & $31.5, \mathrm{CH}_{2}$ & $31.5, \mathrm{CH}_{2}$ \\
\hline 15 & $20.8, \mathrm{CH}_{2}$ & $20.9, \mathrm{CH}_{2}$ & $20.82, \mathrm{CH}_{2}$ & $20.9, \mathrm{CH}_{2}$ \\
\hline 16 & $48.3, \mathrm{CH}$ & $48.3, \mathrm{CH}$ & $48.3, \mathrm{CH}$ & 48.4, $\mathrm{CH}$ \\
\hline 17 & $26.9, \mathrm{CH}_{2}$ & $27.1, \mathrm{CH}_{2}$ & 26.9, $\mathrm{CH}_{2}$ & $27.1, \mathrm{CH}_{2}$ \\
\hline 18 & $115.0, \mathrm{C}$ & $114.8, \mathrm{C}$ & $115.0, \mathrm{C}$ & $114.8, \mathrm{C}$ \\
\hline 19 & $123.3, \mathrm{C}$ & $124.6, \mathrm{C}$ & $123.3, \mathrm{C}$ & $124.6, \mathrm{C}$ \\
\hline 20 & $118.6, \mathrm{CH}$ & $117.5, \mathrm{CH}$ & 118.6, CH & $117.5, \mathrm{CH}$ \\
\hline 21 & $118.7, \mathrm{CH}$ & $118.3, \mathrm{CH}$ & $118.7, \mathrm{CH}$ & $118.3, \mathrm{CH}$ \\
\hline 22 & $123.7, \mathrm{C}$ & $119.1, \mathrm{CH}$ & 123.7, C & $119.1, \mathrm{CH}$ \\
\hline 23 & $111.3, \mathrm{CH}$ & $111.8, \mathrm{CH}$ & $111.3, \mathrm{CH}$ & $111.8, \mathrm{CH}$ \\
\hline 24 & $140.2, \mathrm{C}$ & $139.9, \mathrm{C}$ & $140.2, \mathrm{C}$ & $139.9, \mathrm{C}$ \\
\hline 25 & $16.1, \mathrm{CH}_{3}$ & $16.2, \mathrm{CH}_{3}$ & $16.1, \mathrm{CH}_{3}$ & $16.2, \mathrm{CH}_{3}$ \\
\hline 26 & $23.4, \mathrm{CH}_{3}$ & $23.4, \mathrm{CH}_{3}$ & $23.4, \mathrm{CH}_{3}$ & 23.3, $\mathrm{CH}_{3}$ \\
\hline 27 & $75.0, \mathrm{C}$ & $75.0, \mathrm{C}$ & $75.8, \mathrm{C}$ & $75.8, \mathrm{C}$ \\
\hline 28 & $64.8, \mathrm{CH}_{2}$ & $64.8, \mathrm{CH}_{2}$ & $64.1, \mathrm{CH}_{2}$ & $64.1, \mathrm{CH}_{2}$ \\
\hline 29 & $17.0, \mathrm{CH}_{3}$ & $17.0, \mathrm{CH}_{3}$ & $16.4, \mathrm{CH}_{3}$ & $16.4, \mathrm{CH}_{3}$ \\
\hline $1^{\prime}$ & $170.2, \mathrm{C}$ & $170.2, \mathrm{C}$ & $171.1, \mathrm{C}$ & $171.1, \mathrm{C}$ \\
\hline $2^{\prime}$ & $21.8, \mathrm{CH}_{3}$ & $21.8, \mathrm{CH}_{3}$ & $77.9, \mathrm{C}$ & $77.9, \mathrm{C}$ \\
\hline $3^{\prime}$ & & & $23.9, \mathrm{CH}_{3}$ & 23.9, $\mathrm{CH}_{3}$ \\
\hline $4^{\prime}$ & & & $24.2, \mathrm{CH}_{3}$ & $24.2, \mathrm{CH}_{3}$ \\
\hline $1^{\prime \prime}$ & & & $169.3, \mathrm{C}$ & $169.3, \mathrm{C}$ \\
\hline $2^{\prime \prime}$ & & & $20.75, \mathrm{CH}_{3}$ & $20.8, \mathrm{CH}_{3}$ \\
\hline
\end{tabular}
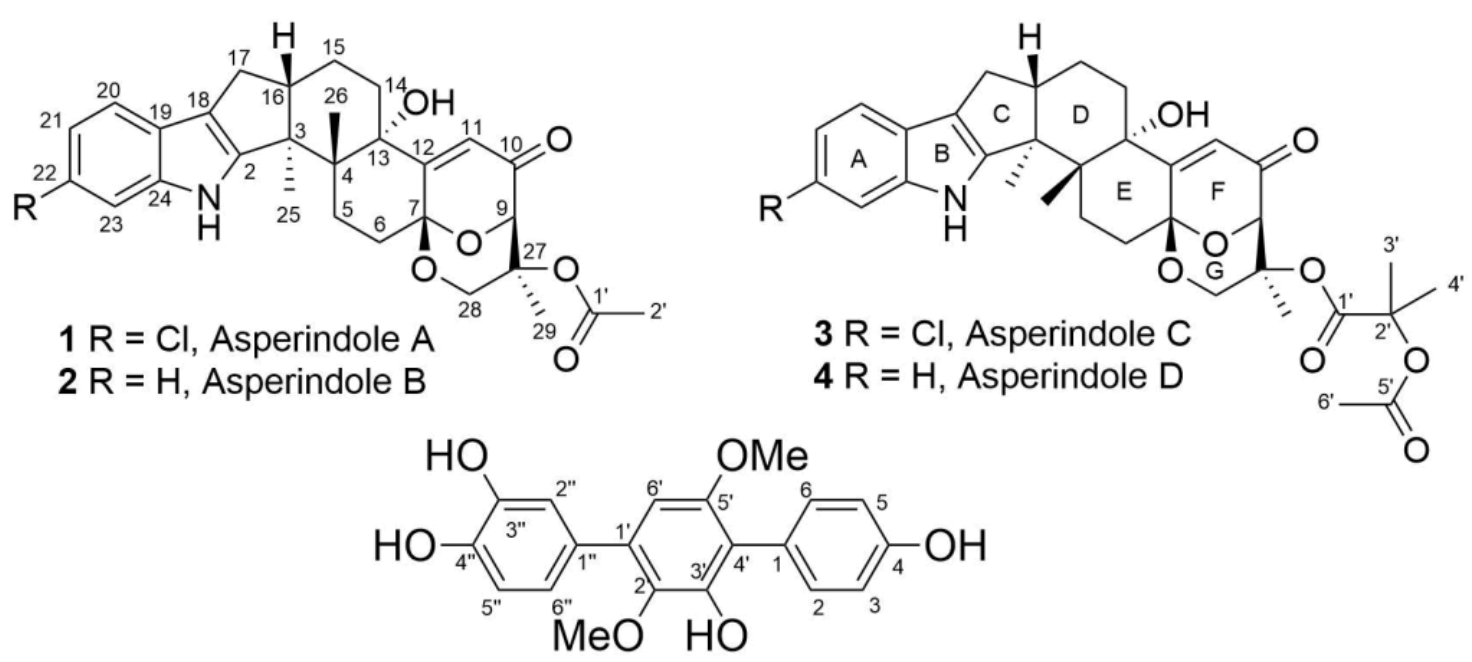

5 3"-hydroxyterphenyllin

Figure 2. Chemical structures of $\mathbf{1 - 5}$. 
The HMBC correlations (Figure 3, Figure S5) from H-28 $\beta\left(\delta_{\mathrm{H}} 3.67\right)$ to $\mathrm{C}-27\left(\delta_{\mathrm{C}} 75.0\right), \mathrm{C}-29\left(\delta_{\mathrm{C}} 17.0\right)$, and $\mathrm{C}-1^{\prime}\left(\delta_{\mathrm{C}} 170.2\right)$; from $\mathrm{H}-9\left(\delta_{\mathrm{H}} 4.74\right)$ to $\mathrm{C}-7\left(\delta_{\mathrm{C}} 93.6\right), \mathrm{C}-28\left(\delta_{\mathrm{C}} 64.8\right)$, and $\mathrm{C}-27$; from H-28 $\alpha\left(\delta_{\mathrm{H}} 4.04\right)$ to $\mathrm{C}-7, \mathrm{C}-9\left(\delta_{\mathrm{C}} 78.3\right)$, and $\mathrm{C}-27$; and from $\mathrm{H}_{3}-29\left(\delta_{\mathrm{H}} 1.21\right)$ to $\mathrm{C}-27$ suggested the presence of a 1,3-dioxane ring with an acetoxy group at $\mathrm{C}-27$. The $\mathrm{W}$-type coupling constant $J_{\mathrm{H} 9-\mathrm{H} 28 \alpha}(2.5 \mathrm{~Hz})$ and ROESY correlations (Figure 4, Figure S6) of $\mathrm{H}-28 \beta$ with $\mathrm{H}-11\left(\delta_{\mathrm{H}} 6.11\right), \mathrm{H}_{3}-29, \mathrm{H}_{3}-26\left(\delta_{\mathrm{H}} 1.02\right)$, and of $\mathrm{H}-28 \alpha$ with $\mathrm{H}_{3}-29$ indicated a relative configuration of chiral centers in the 1,3-dioxane ring as $7 R^{*}, 9 R^{*}$, $27 S^{*}$. The ROESY correlations (Figure 4 , Figure S6) of $\mathrm{H}_{3}-25\left(\delta_{\mathrm{H}} 1.31\right)$ with $\mathrm{H}-5 \alpha\left(\delta_{\mathrm{H}} 1.93\right), 13-\mathrm{OH}$ $\left(\delta_{\mathrm{H}} 5.10\right), \mathrm{H}-6 \alpha\left(\delta_{\mathrm{H}} 2.00\right)$, and $\mathrm{H}-15 \alpha\left(\delta_{\mathrm{H}} 1.91\right)$, and of $\mathrm{H}-16\left(\delta_{\mathrm{H}} 2.72\right)$ with $\mathrm{H}_{3}-26\left(\delta_{\mathrm{H}} 1.02\right)$ suggested the relative configurations of the stereogenic carbons of the $C-G$ rings in 1 as $3 S^{*}, 4 R^{*}, 13 S^{*}, 16 R^{*}$. The absolute configurations of all stereocentres in $\mathbf{1}$ was proposed as $3 S, 4 R, 7 R, 9 R, 13 S, 16 R, 27 S$ - the same as those in paspalinine-based on biosynthetic considerations, and was confirmed by the comparison of the ECD (electronic circular dichroism) spectral data with that of paspalinine [17] (Figure 5). Compound 1 was named asperindole A. It should be noted that chlorinated indolediterpenes are rare in nature [12,22-25].
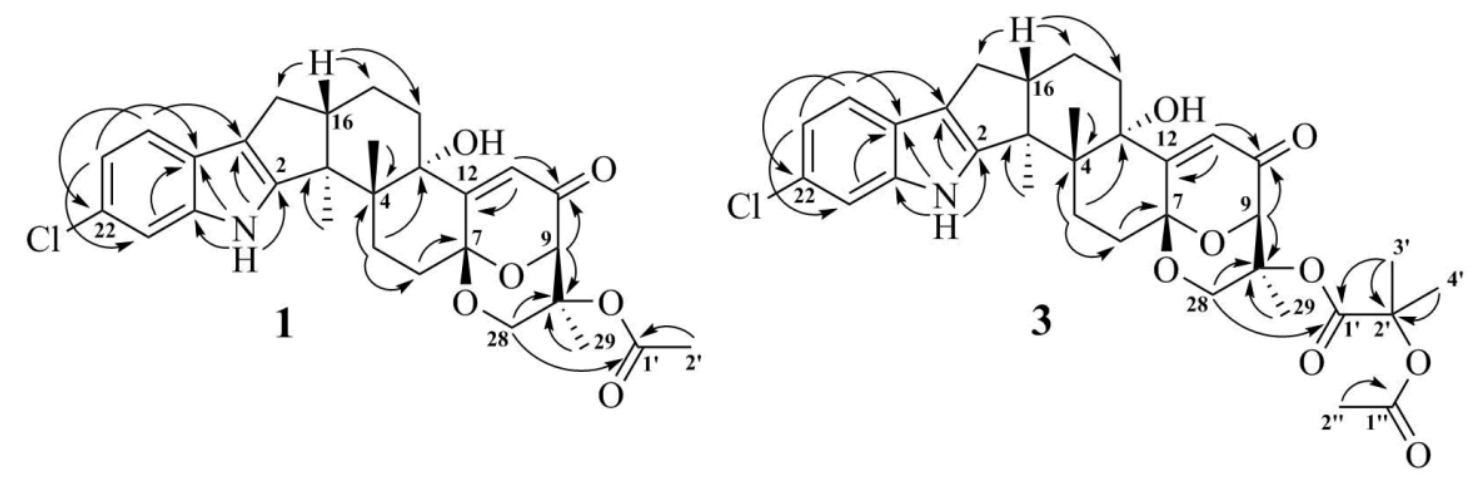

Figure 3. Key HMBC correlations of $\mathbf{1}$ and $\mathbf{3 .}$

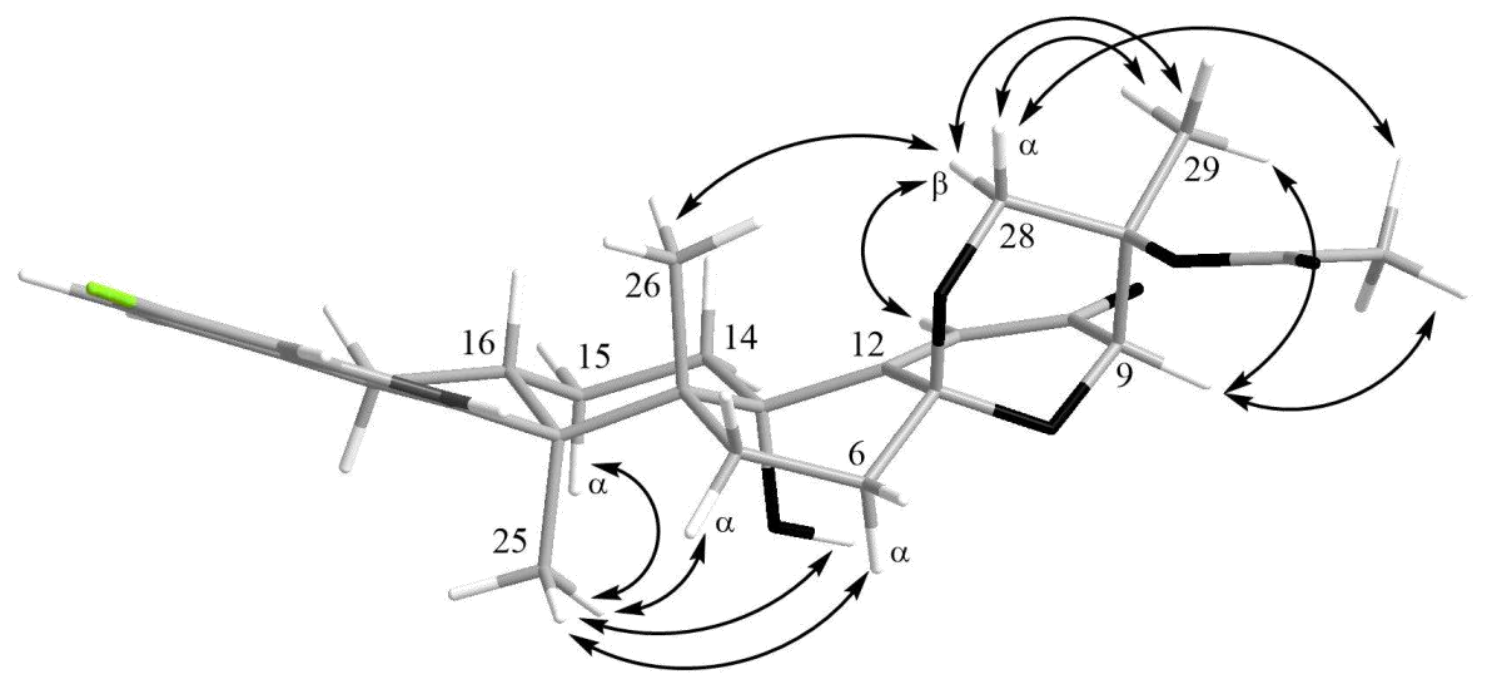

Figure 4. Key ROESY correlations in asperindole A (1).

The molecular formula of 2 was determined as $\mathrm{C}_{29} \mathrm{H}_{33} \mathrm{NO}_{6}$ by a HRESIMS peak at $m / z 490.2188$ $[\mathrm{M}-\mathrm{H}]^{-}$, which was supported by the ${ }^{13} \mathrm{C}$ NMR spectrum. The general features of the ${ }^{1} \mathrm{H}$ and ${ }^{13} \mathrm{C}$ NMR spectra (Table 1, Figures S7 and S8) of 2 resemble those of 1, with the exception of the proton and carbon signals of an indole moiety, as well as the absence of a chlorine atom as evidenced by the HRESIMS spectrum. The coupling constants and the multiplicity of the aromatic protons in ring A $\left(\mathrm{H}-20, \delta_{\mathrm{H}} 7.25, \mathrm{~d}, J=7.6 \mathrm{~Hz} ; \mathrm{H}-21, \delta_{\mathrm{H}} 6.89, \mathrm{t}, J=7.6 \mathrm{~Hz} ; \mathrm{H}-22, \delta_{\mathrm{H}} 6.93, \mathrm{t}, J=7.6 \mathrm{~Hz} ;\right.$ and $\mathrm{H}-23, \delta_{\mathrm{H}} 7.27$, 
$\mathrm{d}, J=7.6 \mathrm{~Hz}$ ) allowed the conclusion to be made that $\mathbf{2}$ is a nonchlorinated analogue of $\mathbf{1}$. Compound $\mathbf{2}$ was therefore named asperindole B.

The molecular formula of 3 was established as $\mathrm{C}_{33} \mathrm{H}_{38} \mathrm{NO}_{8} \mathrm{Cl}$ on the basis of the HRESIMS, containing a peak at $m / z 610.2206[\mathrm{M}-\mathrm{H}]^{-}$, and was supported by the ${ }^{13} \mathrm{C}$ NMR spectrum. The analysis of the NMR data (Figures S14-S20) for 3 revealed the presence of the same indole-diterpene framework as that in 1, with the exception of the proton and carbon signals in a 1,3-dioxane ring, as well as the presence of two methyl $\left(\delta_{C} 23.9,24.2\right)$, an ester carbonyl $\left(\delta_{C} 171.1\right)$, and an oxygen-bearing quaternary $s p^{3}\left(\delta_{\mathrm{C}} 77.9\right)$ carbons. The HMBC correlations (Figure 3, Figure S19) from H-3' $\left(\delta_{\mathrm{H}} 1.52\right)$ and $\mathrm{H}-4^{\prime}\left(\delta_{\mathrm{H}} 1.54\right)$ to $\mathrm{C}-2^{\prime}\left(\delta_{\mathrm{C}} 77.9\right)$, and from $\mathrm{H}-6^{\prime}\left(\delta_{\mathrm{H}} 2.04\right)$ to $\mathrm{C}-5^{\prime}\left(\delta_{\mathrm{C}} 169.3\right)$ suggested the presence of an acetylated residue of 2-hydroxyisobutyric acid (2-HIBA) in 3. This was corroborated by the molecular weight of 3 , which was $86 \mathrm{amu}\left(\mathrm{C}_{4} \mathrm{H}_{6} \mathrm{O}_{2}\right)$ greater than that of $\mathbf{1}$. The ROESY correlations of 3 (Figure S20) were similar to those in $\mathbf{1}$ (Figure 4, Figure S6). Based on these data and together with the ECD spectrum of $\mathbf{1}$ (Figure 5), the absolute configurations of all stereocentres in $\mathbf{3}$ were proposed to be the same as those in asperindole A. Consequently, $\mathbf{3}$ was named asperindole $\mathrm{C}$. To the best of our knowledge, the 2-HIBA residue is unique amongst naturally occurring compounds.

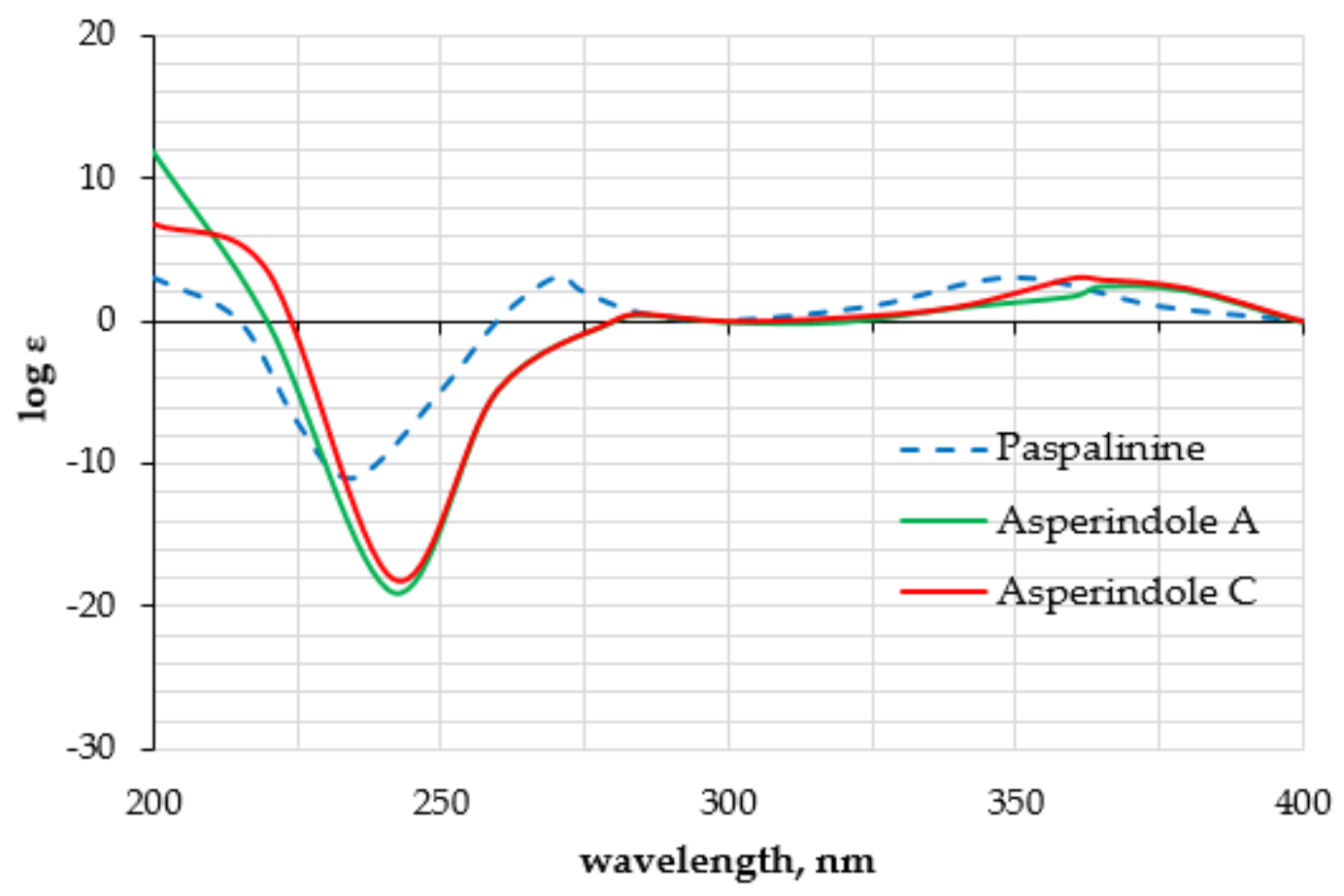

Figure 5. Experimental ECD data of 1, 3, and paspalinine [17].

The HRESIMS spectrum of 4 exhibited the $[\mathrm{M}-\mathrm{H}]^{-}$peak at $m / z 576.2594$, corresponding to $\mathrm{C}_{33} \mathrm{H}_{39} \mathrm{NO}_{8}$, which was supported by the ${ }^{13} \mathrm{C}$ NMR spectrum. The general features of the ${ }^{1} \mathrm{H}$ and ${ }^{13} \mathrm{C}$ NMR spectra (Table 2, Figures S21 and S22) of 4 resembled those of 3, with the exception of some proton and carbon signals of the indole moiety. Similar to 2 , the coupling constants and multiplicity of the aromatic protons in ring A $\left(\mathrm{H}-20, \delta_{\mathrm{H}} 7.25, \mathrm{~d}, J=7.5 \mathrm{~Hz} ; \mathrm{H}-21, \delta_{\mathrm{H}} 6.88, \mathrm{brt}, J=7.2 \mathrm{~Hz} ; \mathrm{H}-22\right.$, $\delta_{\mathrm{H}} 6.92, \mathrm{brt}, J=7.1 \mathrm{~Hz}$; and $\mathrm{H}-23, \delta_{\mathrm{H}} 7.27, \mathrm{~d}, J=6.9 \mathrm{~Hz}$ ) led to the conclusion that 4 is a nonchlorinated analogue of 3 . Compound 4 was therefore named asperindole D. 
Table 2. ${ }^{1} \mathrm{H}$ NMR data $\left(\delta\right.$ in ppm, $J$ in $\mathrm{Hz}$, DMSO- $\left.d_{6}\right)$ for asperindoles A-D (1-4).

\begin{tabular}{|c|c|c|c|c|}
\hline Position & $1 *$ & $2 * *$ & $3 * *$ & $4 * *$ \\
\hline $\mathrm{NH}$ & 10.73, brs & 10.54, brs & $10.73, \mathrm{~s}$ & $10.52, \mathrm{~s}$ \\
\hline $5 \alpha$ & $1.93, \mathrm{~m}$ & $1.96, \mathrm{~m}$ & $1.95, \mathrm{~m}$ & $1.96, \mathrm{~m}$ \\
\hline $5 \beta$ & $2.40, \mathrm{dd}(13.4,10.0)$ & $2.41, \mathrm{t}(12.3)$ & $2.39, \mathrm{dd}(13.4,10.0)$ & $2.41, \mathrm{t}(12.3)$ \\
\hline $6 \alpha$ & $2.00, \mathrm{dd}(12.9,8.6)$ & $1.99, \mathrm{~m}$ & 1.95, dd $(12.9,8.6)$ & 1.95, dd $(12.9,8.6)$ \\
\hline $6 \beta$ & $2.55, \mathrm{~m}$ & $2.55, \mathrm{~m}$ & $2.55, \mathrm{~m}$ & $2.55, \mathrm{~m}$ \\
\hline 9 & $4.74, \mathrm{~d}(2.3)$ & $4.74, \mathrm{~d}(2.1)$ & $4.74, \mathrm{~d}(2.3)$ & $4.63, \mathrm{~d}(2.4)$ \\
\hline 11 & $6.11, \mathrm{~s}$ & $6.11, \mathrm{~s}$ & $6.11, \mathrm{~s}$ & $6.12, \mathrm{~s}$ \\
\hline $14 \alpha$ & $2.11, \mathrm{dt}(13.6,2.8)$ & 2.12, brd (13.4) & $2.12, \mathrm{dt}(13.6,2.8)$ & \\
\hline $14 \beta$ & $1.77, \mathrm{td}(13.2,4.5)$ & 1.78, brt (13.4) & $1.76, \mathrm{td}(13.2,4.5)$ & \\
\hline $15 \alpha$ & $1.91, \mathrm{~m}$ & $1.91, \mathrm{~m}$ & $1.91, \mathrm{~m}$ & $1.91, \mathrm{~m}$ \\
\hline $15 \beta$ & $1.66, \mathrm{~m}$ & $1.66, \mathrm{~m}$ & $1.65, \mathrm{~m}$ & $1.65, \mathrm{~m}$ \\
\hline 16 & $2.72, \mathrm{~m}$ & $2.72, \mathrm{~m}$ & $2.72, \mathrm{~m}$ & $2.63, \mathrm{~m}$ \\
\hline $17 \alpha$ & $2.30, \mathrm{dd}(13.0,10.9)$ & $2.30, \mathrm{t}(12.3)$ & $2.30, \mathrm{dd}(13.0,10.9)$ & $2.31, \mathrm{dd}(13.0,10.9)$ \\
\hline $17 \beta$ & $2.60, \mathrm{dd}(13.0,6.4)$ & 2.60, dd $(12.3,6.6)$ & $2.60, \mathrm{dd}(13.0,6.4)$ & $2.60, \mathrm{dd}(13.0,6.2)$ \\
\hline 20 & $7.26, \mathrm{~d}(8.6)$ & $7.25, \mathrm{~d}(7.6)$ & $7.26, \mathrm{~d}(8.3)$ & $7.25, \mathrm{~d}(7.5)$ \\
\hline 21 & 6.91, dd $(8.3,1.9)$ & $6.89, \mathrm{t}(7.6)$ & $6.91, \mathrm{dd}(8.3,2.0)$ & 6.88, brt $(7.2)$ \\
\hline 22 & & $6.93, \mathrm{t}(7.6)$ & & 6.92, brt $(7.1)$ \\
\hline 23 & $7.27, \mathrm{~d}(2.2)$ & $7.27, \mathrm{~d}(7.6)$ & $7.25, \mathrm{~d}(2.0)$ & $7.27, \mathrm{~d}(6.9)$ \\
\hline 25 & $1.31, \mathrm{~s}$ & $1.30, \mathrm{~s}$ & $1.31, \mathrm{~s}$ & $1.30, \mathrm{~s}$ \\
\hline 26 & $1.02, \mathrm{~s}$ & $1.03, \mathrm{~s}$ & $1.02, \mathrm{~s}$ & $1.03, \mathrm{~s}$ \\
\hline $28 \alpha$ & 4.04, dd $(13.4,2.5)$ & 4.05, dd $(13.3,2.1)$ & $4.11, \mathrm{dd}(13.2,2.5)$ & $4.11, \mathrm{dd}(13.4,2.4)$ \\
\hline $28 \beta$ & $3.67, \mathrm{~d}(13.4)$ & $3.68, \mathrm{~d}(13.3)$ & $3.68, \mathrm{~d}(13.2)$ & $3.69, \mathrm{~d}(13.4)$ \\
\hline 29 & $1.21, \mathrm{~s}$ & $1.21, \mathrm{~s}$ & $1.17, \mathrm{~s}$ & $1.18, \mathrm{~s}$ \\
\hline $3^{\prime}$ & & & $1.52, \mathrm{~s}$ & $1.52, \mathrm{~s}$ \\
\hline $4^{\prime}$ & & & $1.54, \mathrm{~s}$ & $1.54, \mathrm{~s}$ \\
\hline $2^{\prime \prime}$ & $2.07, \mathrm{~s}$ & $2.07, \mathrm{~s}$ & $2.04, \mathrm{~s}$ & $2.04, \mathrm{~s}$ \\
\hline $13-\mathrm{OH}$ & $5.10, \mathrm{~s}$ & $5.08, \mathrm{~s}$ & $5.11, \mathrm{~s}$ & $5.08, \mathrm{~s}$ \\
\hline
\end{tabular}

${ }^{1} \mathrm{H}$ NMR spectroscopic data were measured at * $700 \mathrm{MHz}$ and ${ }^{* *} 500 \mathrm{MHz}$, respectively.

The molecular formula of 5 was determined as $\mathrm{C}_{20} \mathrm{H}_{18} \mathrm{O}_{6}$, based on a pseudo-molecular peak at $m / z 353.1013[\mathrm{M}-\mathrm{H}]^{-}$from the HRESIMS spectrum. This was supported by the ${ }^{13} \mathrm{C}$ NMR spectrum. A close inspection of the ${ }^{1} \mathrm{H}$ and ${ }^{13} \mathrm{C}$ NMR data (Table 3, Figures S23 and S24) of 5 revealed the presence of eight aromatic protons $\left(\delta_{\mathrm{H}} 6.47,6.85,2 \mathrm{H} ; 6.91,7.02,7.19,7.25,2 \mathrm{H}\right)$ and eight methine $s p^{2}\left(\delta_{C} 104.8,115.9,115.9,116.8,117.5,122.0,133.7,133.7\right)$, six oxygen-bearing quaternary $s p^{2}\left(\delta_{C} 140.8,146.3,146.4,149.8,155.1,157.6\right)$, and four quaternary $s p^{2}\left(\delta_{C} 118.3,126.8,131.9,134.2\right)$ carbons, and two methoxy groups $\left(\delta_{\mathrm{C}} 56.8,61.4 ; \delta_{\mathrm{H}} 3.41,3.71\right)$. A direct comparison of ${ }^{1} \mathrm{H}$ and ${ }^{13} \mathrm{C}$ NMR spectra of 5 (Table 3, Figures S23 and S24) with those of terphenyllin [1] showed their close resemblance, with the exception of the presence of a hydroxy group at C-3" $\left(\delta_{\mathrm{C}} 146.4\right)$ and the difference in carbon chemical shifts at C-2" $\left(\delta_{\mathrm{C}} 117.5\right), \mathrm{C}-4^{\prime \prime}\left(\delta_{\mathrm{C}} 146.3\right), \mathrm{C}-5^{\prime \prime}\left(\delta_{\mathrm{C}} 116.8\right)$ and C-6" $\left(\delta_{\mathrm{C}} 122.0\right)$ (131.1 ppm for C-1", C-2", and C-6"; $158.0 \mathrm{ppm}$ for C-4" in terphenyllin [1]). The HMBC correlations (Figure 6, Figure S27) from H-2 $\left(\delta_{\mathrm{H}} 7.25\right)$ to C-4 $\left(\delta_{\mathrm{C}} 157.6\right), \mathrm{C}-6\left(\delta_{\mathrm{C}} 133.7\right)$, and C-4 ${ }^{\prime}\left(\delta_{\mathrm{C}}\right.$ $118.3)$; from $\mathrm{H}-3\left(\delta_{\mathrm{H}} 6.85\right)$ to $\mathrm{C}-1\left(\delta_{\mathrm{C}} 126.8\right)$ and C-5 $\left(\delta_{\mathrm{C}} 115.9\right)$; from $\mathrm{H}-5\left(\delta_{\mathrm{H}} 6.85\right)$ to $\mathrm{C}-3\left(\delta_{\mathrm{C}} 115.9\right)$ and C-1; from H-6 $\left(\delta_{\mathrm{H}} 7.25\right)$ to $\mathrm{C}-2\left(\delta_{\mathrm{C}} 133.7\right), \mathrm{C}-4$, and C-4 ${ }^{\prime}$; from H-6 ${ }^{\prime}\left(\delta_{\mathrm{H}} 6.47\right)$ to C-2' $\left(\delta_{\mathrm{C}} 140.8\right)$, C-4 ${ }^{\prime}$, and C-1" $\left(\delta_{\mathrm{C}} 131.9\right)$; from H-2" $\left(\delta_{\mathrm{H}} 7.19\right)$ to C-1' $\left(\delta_{\mathrm{C}} 134.2\right), \mathrm{C}-4^{\prime \prime}$, and C-6"; from H-5" $\left(\delta_{\mathrm{H}} 6.91\right)$ to C-1" and C-3"; from H-6" ( $\left.\delta_{\mathrm{H}} 7.50\right)$ to C-1', C-2", and C-4"; and ROESY correlation from H-6 and $2^{\prime}-\mathrm{OMe}\left(\delta_{\mathrm{H}} 3.41\right)$ to $\mathrm{H}-2^{\prime \prime}$ and $\mathrm{H}-6^{\prime \prime}$, and from $5^{\prime}$-OMe $\left(\delta_{\mathrm{H}} 3.71\right)$ to $\mathrm{H}-2(\mathrm{H}-6)$ established the structure of 5 as the $2^{\prime}, 5^{\prime}$-dimethoxy-4, $3^{\prime}, 3^{\prime \prime}, 4^{\prime \prime}$-tetrahydroxy-p-terphenyl derivative. This structure was previously published as hydroxyterphenyllin in an unavailable source [26]. It should be noted that these authors reported the name "hydroxyterphenyllin" for an isomeric compound [27] now known as 3-hydroxyterphenyllin [2,28]. Probably, the structure of $\mathbf{5}$ was mistakenly provided by [26] instead of the structure of 3-hydroxyterphenyllin. Therefore, 5 should be named 3"-hydroxyterphenyllin. 


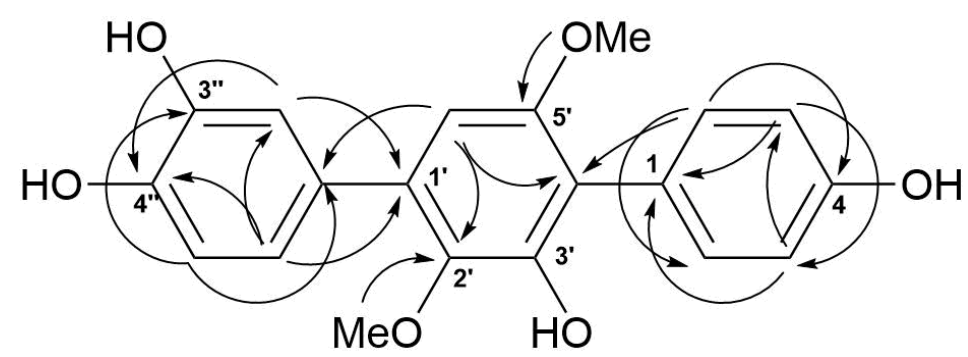

Figure 6. Key HMBC correlations of 5.

Table 3. ${ }^{1} \mathrm{H}$ and ${ }^{13} \mathrm{C}$ NMR data ( $\delta$ in ppm, DMSO- $\left.d_{6}\right)$ for 3 "-hydroxyterphenyllin (5).

\begin{tabular}{|c|c|c|c|c|}
\hline Position & $\delta_{\mathrm{C}}$, mult & $\delta_{\mathrm{H}}(J$ in $\mathrm{Hz})$ & НМВС & ROESY \\
\hline 1 & $126.8, \mathrm{C}$ & & & \\
\hline 2 & 133.7, $\mathrm{CH}$ & $7.25, \mathrm{~d}(8.4)$ & $4,6,4^{\prime}$ & \\
\hline 3 & $115.9, \mathrm{CH}$ & $6.85, \mathrm{~d}(8.5)$ & 1,5 & \\
\hline 4 & $157.6, \mathrm{C}$ & & & \\
\hline 5 & $115.9, \mathrm{CH}$ & $6.85, \mathrm{~d}(8.5)$ & 1,3 & \\
\hline 6 & 133.7, $\mathrm{CH}$ & $7.25, \mathrm{~d}(8.4)$ & $2,4,4^{\prime}$ & $5^{\prime}-\mathrm{OMe}$ \\
\hline $1^{\prime}$ & $134.2, \mathrm{C}$ & & & \\
\hline $2^{\prime}$ & $140.8, \mathrm{C}$ & & & \\
\hline $3^{\prime}$ & $149.8, \mathrm{C}$ & & & \\
\hline $4^{\prime}$ & $118.3, \mathrm{C}$ & & & \\
\hline $5^{\prime}$ & $155.1, \mathrm{C}$ & & & \\
\hline $6^{\prime}$ & $104.8, \mathrm{CH}$ & $6.47, \mathrm{~s}$ & $2^{\prime}, 4^{\prime}, 1^{\prime \prime}$ & $2^{\prime \prime}, 6^{\prime \prime}$ \\
\hline $1^{\prime \prime}$ & $131.9, \mathrm{C}$ & & & \\
\hline $2^{\prime \prime}$ & $117.5, \mathrm{CH}$ & $7.19, \mathrm{~d}(2.1)$ & $1^{\prime}, 4^{\prime \prime}, 6^{\prime \prime}$ & $6^{\prime}, 2^{\prime}-\mathrm{OMe}$ \\
\hline $3 "$ & $146.4, \mathrm{C}$ & & & \\
\hline $4^{\prime \prime}$ & $146.3, \mathrm{C}$ & & & \\
\hline $5^{\prime \prime}$ & $116.8, \mathrm{CH}$ & $6.91, \mathrm{~d}(8.1)$ & $1^{\prime \prime}, 3^{\prime \prime}$ & \\
\hline 6" & $122.0, \mathrm{CH}$ & $7.02, \mathrm{dd}(8.1,2.1)$ & $1^{\prime}, 2^{\prime \prime}, 4^{\prime \prime}$ & $6^{\prime}, 2^{\prime}-\mathrm{OMe}$ \\
\hline $2^{\prime}-\mathrm{OMe}$ & $61.4, \mathrm{CH}_{3}$ & $3.41, \mathrm{~s}$ & $2^{\prime}$ & $2^{\prime \prime}, 6^{\prime \prime}$ \\
\hline $5^{\prime}-\mathrm{OMe}$ & $56.8, \mathrm{CH}_{3}$ & $3.71, \mathrm{~s}$ & $5^{\prime}$ & 6 \\
\hline
\end{tabular}

The biosynthesis of related indole-diterpenes was previously proposed for paspalinine [29]. Apparently, the common biosynthetic precursor of asperindoles and 1,3-dioxolane indole-diterpenoids (including paspalinine) is $7 \alpha$-hydroxypaxilline (Figure 7). Oxidation of the isopropyl substituent, followed by cyclization at C-7 and C-2' , generates a 1,3-dioxane ring. Asperindoles are then formed by acylation and halogenation.

The effect of the asperindoles A (1) and C (3) on cell viability, cell cycle progression, and induction of apoptosis in human prostate cancer cell lines was investigated. MTT assays revealed that asperindole C (3) was noncytotoxic against human PC-3, LNCaP (androgen-sensitive human prostate adenocarcinoma cells), and $22 \mathrm{Rv} 1$ cell lines with an $\mathrm{IC}_{50}>100 \mu \mathrm{M}$. In contrast, asperindole A (1) showed cytotoxicity in all three cell lines, with $\mathrm{IC}_{50}$ values of $69.4 \mu \mathrm{M}, 47.8 \mu \mathrm{M}$, and $4.86 \mu \mathrm{M}$, respectively. Docetaxel, which was used as a reference substance, displayed $\mathrm{IC}_{50}$ values of $15.4 \mathrm{nM}$, $3.8 \mathrm{nM}$, and $12.7 \mathrm{nM}$, respectively. Asperindole A (1) was able to induce apoptosis in human cancer 22Rv1 cells at low-micromolar concentrations (Figure 8). Cell cycle progression analysis of 22Rv1 cells treated with asperindole A (1) for $48 \mathrm{~h}$ revealed a S-phase arrest (as well as a discrete G2/M-phase arrest, Figure 8). Thus, asperindole A (1) may be a promising candidate for further studies in human drug-resistant prostate cancer. In contrast, 22Rv1 cells treated with $100 \mu \mathrm{M}$ of asperindole C (3) for $48 \mathrm{~h}$ revealed only minimal induction of apoptosis $(8.9 \pm 0.6 \%$ vs $1.2 \pm 0.1 \%$ in the control) and no significant changes in cell cycle progression. 


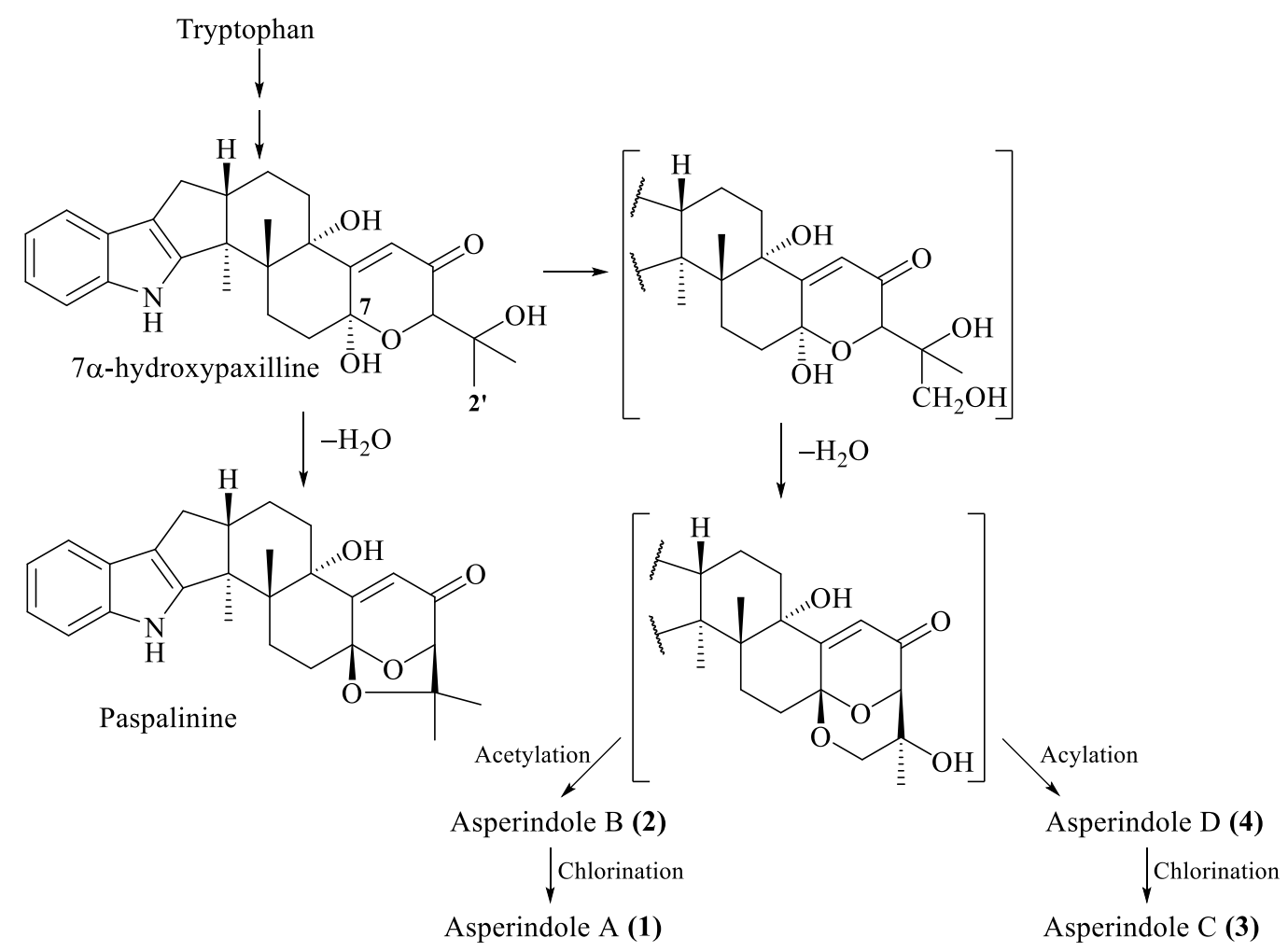

Figure 7. Proposed biosynthesis of asperindoles A-D (1-4).

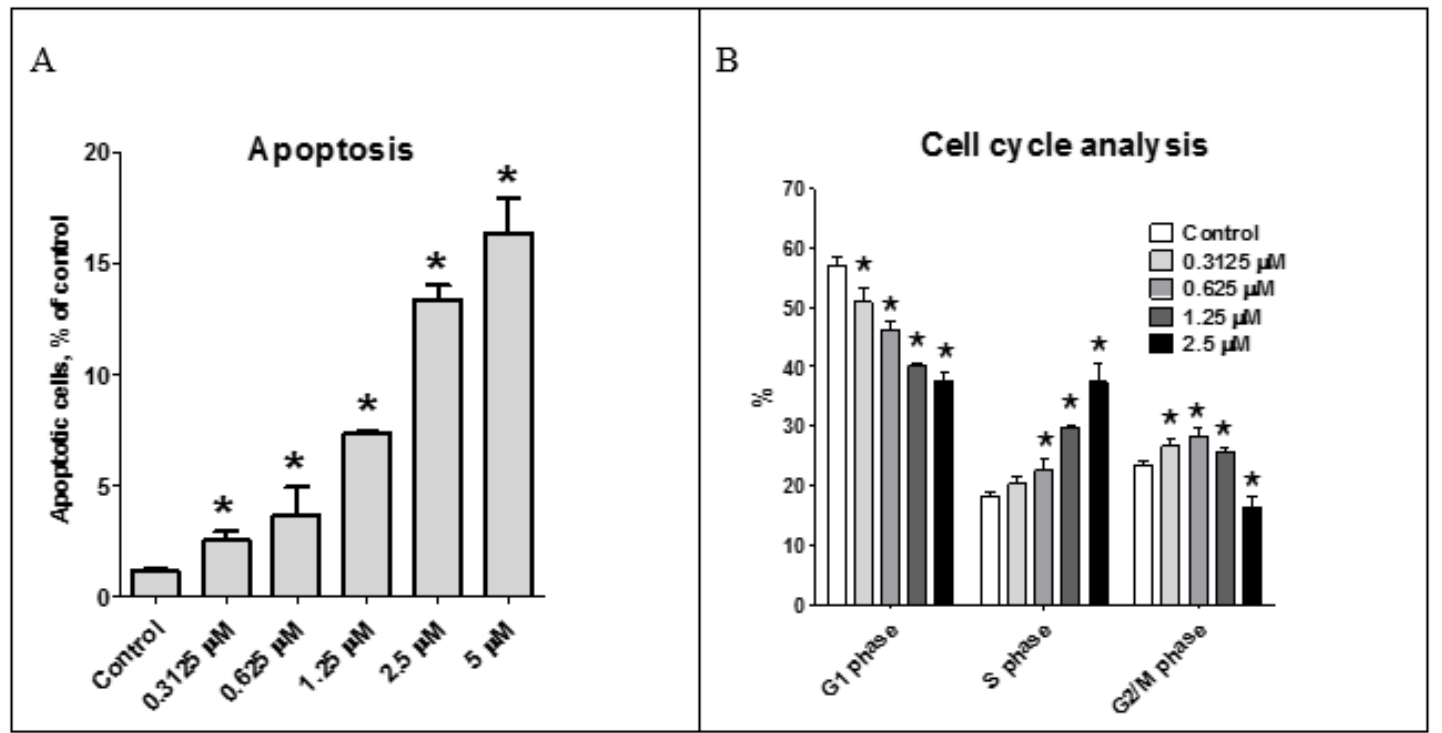

Figure 8. Effect of asperindole A (1) on cell cycle progression and apoptosis induction. Apoptotic cells were detected as a sub-G1 population (A); Cell cycle analysis of 22Rv1 cells treated with asperindole A (1) for $48 \mathrm{~h}$ (B). Cell cycle phase distribution, quantified using the Cell Quest Pro software. ${ }^{*} p<0.05$.

\section{Materials and Methods}

\subsection{General Experimental Procedures}

Optical rotations were measured on a Perkin-Elmer 343 polarimeter (Perkin Elmer, Waltham, MA, USA). UV spectra were recorded on a Specord UV - vis spectrometer (Carl Zeiss, Jena, Germany) 
in $\mathrm{CHCl}_{3}$. NMR spectra were recorded in DMSO- $d_{6}$ on a Bruker DPX-500 (Bruker BioSpin GmbH, Rheinstetten, Germany) and a Bruker DRX-700 (Bruker BioSpin GmbH, Rheinstetten, Germany) spectrometer, using TMS as an internal standard. HRESIMS spectra were measured on an Agilent 6510 Q-TOF LC mass spectrometer (Agilent Technologies, Santa Clara, CA, USA) and a Maxis impact mass spectrometer (Bruker Daltonics GmbH, Rheinstetten, Germany).

Low-pressure liquid column chromatography was performed using silica gel (50/100 $\mu \mathrm{m}$, Imid, Russia). Plates $(4.5 \mathrm{~cm} \times 6.0 \mathrm{~cm})$ precoated with silica gel $(5-17 \mu \mathrm{m}$, Imid) were used for thin-layer chromatography. Preparative HPLC was carried out on a Shimadzu LC-20 chromatograph (Shimadzu USA Manufacturing, Canby, OR, USA) using a YMC ODS-AM (YMC Co., Ishikawa, Japan) (5 $\mu \mathrm{m}$, $10 \mathrm{~mm} \times 250 \mathrm{~mm}$ ) and YMC SIL (YMC Co., Ishikawa, Japan) $(5 \mu \mathrm{m}, 10 \mathrm{~mm} \times 250 \mathrm{~mm})$ columns with a Shimadzu RID-20A refractometer (Shimadzu Corporation, Kyoto, Japan).

\subsection{Fungal Strain}

The strain was isolated from an unidentified colonial ascidian (Shikotan Island, Pacific Ocean) on malt extract agar, and identified on the basis of morphological and molecular features. For DNA extraction, the culture was grown on malt extract agar under $25^{\circ} \mathrm{C}$ for 7 days. DNA extraction was performed with the HiPurATM Plant DNA Isolation kit (CTAB Method) (HiMedia Laboratories Pvt. Ltd., Mumbai, India) according to the manufacturer's instructions. Fragments containing the ITS (internal transcribed spacer) regions were amplified using ITS1 and ITS4 primers. The newly obtained sequences were checked visually and compared to available sequences in the GenBank database (www.mycobank.org). According to BLAST analysis of the ITS1-5.8S-ITS2 sequence, the strain KMM 4676 had $98 \%$ similarity with Aspergillus candidus. The sequences were deposited in the GenBank nucleotide sequence database under MG 241226. The strain is deposited in the Collection of Marine Microorganisms of G. B. Elyakov Pacific Institute of Bioorganic Chemistry FEB RAS under the code KMM 4676.

\subsection{Cultivation of Fungus}

The fungus was cultured at $22{ }^{\circ} \mathrm{C}$ for three weeks in $14 \times 500 \mathrm{~mL}$ Erlenmeyer flasks, each containing rice $(20.0 \mathrm{~g})$, yeast extract $(20.0 \mathrm{mg}), \mathrm{KH}_{2} \mathrm{PO}_{4}(10 \mathrm{mg})$, and natural sea water $(40 \mathrm{~mL})$.

\subsection{Extraction and Isolation}

The fungal mycelia with the medium were extracted for $24 \mathrm{~h}$ with $5.6 \mathrm{~L}$ of EtOAc. Evaporation of the solvent under reduced pressure gave a dark brown oil (6.25 g), to which $250 \mathrm{~mL} \mathrm{H}_{2} \mathrm{O}-\mathrm{EtOH}(4: 1)$ was added, and the mixture was thoroughly stirred to yield a suspension. It was extracted successively with $n$-hexane $(150 \mathrm{~mL} \times 2)$, EtOAc $(150 \mathrm{~mL} \times 2)$, and $n$-BuOH $(150 \mathrm{~mL} \times 2)$. After evaporation of the EtOAc layer, the residual material $(3.92 \mathrm{~g})$ was passed over a silica gel column $(35.0 \mathrm{~cm} \times 2.5 \mathrm{~cm}, 75 \mathrm{~g})$, which was eluted first with $n$-hexane $(1.0 \mathrm{~L}$ ), followed by a step gradient from $5 \%$ to $100 \%$ EtOAc in $n$-hexane (total volume $30 \mathrm{~L}$ ). Fractions of $250 \mathrm{~mL}$ each were collected and combined on the basis of TLC (Si gel, toluene-2-propanol, 6:1 and 3:1, $v / v$ ).

The $n$-hexane-EtOAc (9:1, $2 \mathrm{~L}, 21.70 \mathrm{mg})$ fraction was purified by LH-20 column $(80 \mathrm{~cm} \times 2 \mathrm{~cm}, 50 \mathrm{~g})$ with $\mathrm{CHCI}_{3}$ to yield 30 subfractions. Subfraction 6 is the individual compound $\mathbf{1}(8.30 \mathrm{mg})$. Subfractions 8-12 (7.00 mg) were purified by HPLC on a YMC ODS-AM column, eluting with $\mathrm{MeOH}-\mathrm{H}_{2} \mathrm{O}(9: 1)$, and then by HPLC on a YMC SIL column, eluting with acetone- $n$-hexane (1:3) to yield $2(0.56 \mathrm{mg})$, $3(1.05 \mathrm{mg})$, and $4(1.47 \mathrm{mg})$. The $n$-hexane-EtOAc $(4: 1,2 \mathrm{~L}, 145 \mathrm{mg})$ fraction was purified by by HPLC on a YMC ODS-AM column, eluting with $\mathrm{MeOH}-\mathrm{H}_{2} \mathrm{O}$ (13:7), then by HPLC on a YMC-SIL column eluting first with $\mathrm{CHCl}_{3}-\mathrm{MeOH}-\mathrm{NH}_{4} \mathrm{OAc}$ (90:10:1.5), and then with $\mathrm{CHCl}_{3}-\mathrm{MeOH}-\mathrm{NH}_{4} \mathrm{OAc}$ (85:15:1) to yield 5 (56.10 mg).

Asperindole A (1): white powder; $[\alpha]_{D}^{20}+22\left(c 0.10, \mathrm{CHCl}_{3}\right) ; \mathrm{UV}(\mathrm{MeOH}) \lambda_{\max }(\log \varepsilon) 284$ (3.86), 236.4 (4.55), $195.6(4.55) \mathrm{nm} ; \mathrm{ECD}(0.21 \mathrm{mM}, \mathrm{MeOH}) \lambda_{\max }(\Delta \varepsilon) 205$ (+8.52), 240 (-19.80), $280(+0.25)$, 
$360(+3.60) \mathrm{nm} ;{ }^{1} \mathrm{H}$ and ${ }^{13} \mathrm{C}$ NMR data see Table 1, Figures S1-S6; HR ESIMS $m / z 526.1980[\mathrm{M}+\mathrm{H}]^{+}$ (calcd. for $\mathrm{C}_{29} \mathrm{H}_{33} \mathrm{NO}_{6} \mathrm{Cl}, 526.1992, \Delta-2.28 \mathrm{ppm}$ ).

Asperindole B (2): white powder; $[\alpha]_{D}^{20}+40\left(c 0.03, \mathrm{CHCl}_{3}\right) ;{ }^{1} \mathrm{H}$ and ${ }^{13} \mathrm{C}$ NMR data see Table 1 , Figures S7-S13; HRESIMS $m / z 514.2194[\mathrm{M}+\mathrm{Na}]^{+}$(calcd. for $\mathrm{C}_{29} \mathrm{H}_{33} \mathrm{NO}_{6} \mathrm{Na}, 514.2200, \Delta-1.17 \mathrm{ppm}$ ). Asperindole C (3): white powder; $[\alpha]_{D}^{20}+46\left(c 0.72, \mathrm{CHCl}_{3}\right)$; UV (MeOH) $\lambda_{\max }(\log \varepsilon) 284(3.90)$, 236.4 (4.56), $194.8(4.46) \mathrm{nm} ; \mathrm{ECD}(0.21 \mathrm{mM}, \mathrm{MeOH}) \lambda_{\max }(\Delta \varepsilon) 205$ (+6.43), 240 (-18.25), 280 (+0.02), $360(+3.57) \mathrm{nm} ;{ }^{1} \mathrm{H}$ and ${ }^{13} \mathrm{C}$ NMR data see Table 2, Figures S14-S20; HRESIMS $m / z$ 610.2206 [M - H] ${ }^{-}$ (calcd. for $\mathrm{C}_{33} \mathrm{H}_{37} \mathrm{NO}_{8} \mathrm{Cl}, 610.2213, \Delta-1.15 \mathrm{ppm}$ ).

Asperindole D (4): white powder; $[\alpha]_{D}^{20}+24\left(c 0.05, \mathrm{CHCl}_{3}\right) ;{ }^{1} \mathrm{H}$ and ${ }^{13} \mathrm{C}$ NMR data, see Table 2, Figures S21 and S22; HRESIMS $m / z$ 576.2594 [M - H] $]^{-}$(calcd. for $\mathrm{C}_{33} \mathrm{H}_{38} \mathrm{NO}_{8}, 576.2603, \Delta-1.56 \mathrm{ppm}$ ). 3"-hydroxyterphenylline (5): ${ }^{1} \mathrm{H}$ and ${ }^{13} \mathrm{C}$ NMR data, see Table 3, Figures S23-S27; HRESIMS $\mathrm{m} / \mathrm{z}$ $353.1036[\mathrm{M}-\mathrm{H}]^{-}$(calcd. for $\mathrm{C}_{20} \mathrm{H}_{17} \mathrm{O}_{6}, 353.1031, \Delta-1.42 \mathrm{ppm}$ ).

\subsection{Cell Culture}

The human prostate cancer cells lines 22Rv1, PC-3, and LNCaP were purchased from ATCC. Cell lines were cultured in 10\% FBS/RPMI media (Invitrogen Ltd., Paisley, UK) with (for LNCaP) or without (for 22Rv1 and PC-3) $1 \mathrm{mM}$ sodium pyruvate (Invitrogen). Cells were continuously kept in culture for a maximum of 3 months, and were routinely inspected microscopically for stable phenotype and regularly checked for contamination with mycoplasma. Cell line authentication was performed by DSMZ (Braunschweig, Germany) using highly polymorphic short tandem repeat loci [30].

\subsection{Cytotoxicity Assay}

The in vitro cytotoxicity of individual substances was evaluated using the MTT (3-(4,5-dimethylthiazol-2-yl)-2,5-diphenyltetrazolium bromide) assay, which was performed as previously described [31]. Docetaxel was used as a control.

\subsection{Cell Cycle and Apoptosis Induction Analysis}

The cell cycle distribution was analyzed by flow cytometry using PI (propidium iodide) staining as described before with slight modifications [32]. In brief, cells were preincubated overnight in 6-well plates $\left(2 \times 10^{5}\right.$ cells/well in $2 \mathrm{~mL} /$ well $)$. The medium was changed to fresh medium containing different concentrations of the substances. After $48 \mathrm{~h}$ of treatment, cells were harvested with a trypsin-EDTA solution, fixed with 70\% EtOH, stained, and analyzed by BD Bioscience FACS Calibur analyzer (BD Bioscience, Bedford, MA, USA). The results were quantitatively analyzed using BD Bioscience Cell Quest Pro v.5.2.1. software (San Jose, CA, USA). Cells detected in the sub-G1 peak were considered as apoptotic.

\section{Conclusions}

Four new metabolites, the indole-diterpene alkaloids asperindoles A-D (1-4), and the known $p$-terphenyl derivative $3^{\prime \prime}$-hydroxyterphenyllin (5) were isolated from a marine-derived strain of the fungus $A$. candidus KMM 4676, associated with an unidentified colonial ascidian. To the best of our knowledge, 3 and 4 are the first examples of naturally occurring compounds containing a 2-hydroxyisobutiric acid (2-HIBA) residue. This is the first report of the spectral data and reliable assignment for $3^{\prime \prime}$-hydoxyterphenyllin (5). Asperindole A (1) was proved to be highly cytotoxic in 22Rv1 human prostate cancer cells resistant to androgen receptor-targeted therapies. Therefore, this compound is a promising candidate for further evaluation in human drug-resistant prostate cancer cells.

Supplementary Materials: ${ }^{1} \mathrm{H},{ }^{13} \mathrm{C}$, DEPT, COSY-45, HSQC, HMBC, and ROESY spectra of new compounds 1-5 are available online at http:/ / www.mdpi.com/1660-3397/16/7/232/s1. 
Author Contributions: Conceptualization, A.N.Y.; Data curation, A.N.Y. and S.A.D.; Formal analysis, A.N.Y.; Funding acquisition, G.v.A. and S.S.A.; Investigation, E.V.I., A.N.Y., O.F.S., A.B.R., O.I.Z., M.V.P., R.S.P. and S.A.D.; Methodology, A.N.Y., G.v.A. and S.A.D.; Project administration, G.v.A. and S.S.A.; Resources, A.N.Y. and G.v.A.; Supervision, S.S.A.; Validation, S.A.D.; Visualization, E.V.I.; Writing-original draft, E.V.I., M.V.P. and S.A.D.; Writing-review \& editing, A.N.Y., G.v.A., S.S.A. and S.A.D.

Acknowledgments: The study was supported by the Federal Agency for Scientific Organizations program for support to bioresource collections. The authors thank Friedemann Honecker for thorough English editing.

Conflicts of Interest: The authors declare no conflict of interest.

\section{References}

1. Marchelli, R.; Vining, L.C. Terphenyllin, a novel p terphenyl metabolite from Aspergillus candidus. J. Antibiot. 1975, 28, 328-331. [CrossRef] [PubMed]

2. Kurobane, I.; Vining, L.C.; McInnes, A.G.; Smith, D.G. 3-Hydroxyterphenyllin, a new metabolite of Aspergillus candidus. Structure elucidation by $1 \mathrm{H}$ and $13 \mathrm{C}$ nuclear magnetic resonance spectroscopy. J. Antibiot. 1979, 32, 559-564. [CrossRef] [PubMed]

3. Kamigauchi, T.; Sakazaki, R.; Nagashima, K.; Kawamura, Y.; Yasuda, Y.; Matsushima, K.; Tani, H.; Takahashi, Y.; Ishii, K.; Suzuki, R.; et al. Terprenins, novel immunosuppressants produced by Aspergillus candidus. J. Antibiot. 1998, 51, 445-450. [CrossRef] [PubMed]

4. Rahbæk, L.; Frisvad, J.C.; Christophersen, C. An amendment of Aspergillus section Candidi based on chemotaxonomical evidence. Phytochemistry 2000, 53, 581-586. [CrossRef]

5. Cai, S.; Sun, S.; Zhou, H.; Kong, X.; Zhu, T.; Li, D.; Gu, Q. Prenylated polyhydroxy-p-terphenyls from Aspergillus taichungensis ZHN-7-07. J. Nat. Prod. 2011, 74, 1106-1110. [CrossRef] [PubMed]

6. Bird, A.E.; Marshall, A.C. Structure of chlorflavonin. J. Chem. Soc. C 1969, 18, 2418-2420. [CrossRef]

7. Yan, T.; Guo, Z.K.; Jiang, R.; Wei, W.; Wang, T.; Guo, Y.; Song, Y.C.; Jiao, R.H.; Tan, R.X.; Ge, H.M. New Flavonol and Diterpenoids from the Endophytic Fungus Aspergillus sp. YXf3. Planta Med. 2013, 79, 348-352. [CrossRef] [PubMed]

8. Kuhnert, E.; Surup, F.; Herrmann, J.; Huch, V.; Müller, R.; Stadler, M.; Rickenyls, A.-E. antioxidative terphenyls from the fungus Hypoxylon rickii (Xylariaceae, Ascomycota). Phytochemistry 2015, 118, 68-73. [CrossRef] [PubMed]

9. Valeria Calì, C.S.; Tringali, C. Polyhydroxy-P-Terphenyls and Related P-Terphenylquinones From Fungi: Overview and Biological Properties. Stud. Nat. Prod. Chem. 2003, 29, 263-307.

10. Kobayashi, A.; Takemoto, A.; Koshimizu, K.; Kawazu, K. p-Terphenyls with cytotoxic activity toward sea urchin embryos. Agric. Biol. Chem. 1985, 49, 867-868. [CrossRef]

11. Buttachon, S.; Ramos, A.A.; Inácio, Â.; Dethoup, T.; Gales, L.; Lee, M.; Costa, P.M.; Silva, A.M.S.; Sekeroglu, N.; Rocha, E.; et al. Bis-indolyl benzenoids, hydroxypyrrolidine derivatives and other constituents from cultures of the marine sponge-associated fungus Aspergillus candidus KUFA0062. Mar. Drugs 2018, 16, 119. [CrossRef] [PubMed]

12. Netz, N.; Opatz, T. Marine indole alkaloids. Mar. Drugs 2015, 13, 4814-4914. [CrossRef] [PubMed]

13. Munday-Finch, S.C.; Miles, C.O.; Wilkins, A.L.; Hawkes, A.D. Isolation and Structure Elucidation of Lolitrem A, a Tremorgenic Mycotoxin from Perennial Ryegrass Infected with Acremonium lolii. J. Agric. Food Chem. 1995, 43, 1283-1288. [CrossRef]

14. Gallagher, R.T.; White, E.P.; Mortimer, P.H. Ryegrass staggers: Isolation of potent neurotoxins lolitrem a and lolitrem b from staggers-producing pastures. N. Z. Vet. J. 1981, 29, 189-190. [CrossRef] [PubMed]

15. Munday-Finch, S.C.; Wilkins, A.L.; Miles, C.O.; Tomoda, H.; Omura, S. Isolation and Structure Elucidation of Lolilline, a Possible Biosynthetic Precursor of the Lolitrem Family of Tremorgenic Mycotoxins. J. Agric. Food Chem. 1997, 45, 199-204. [CrossRef]

16. Gallagher, R.T.; Finer, J.; Clardy, J.; Leutwiler, A.; Weibel, F.; Acklin, W.; Arigoni, D. Paspalinine, a Tremorgenic Metabolite from Claviceps paspali Stevens Et Hall. Tetrahedron Lett. 1980, 21, 235-238. [CrossRef]

17. Sun, K.; Li, Y.; Guo, L.; Wang, Y.; Liu, P.; Zhu, W. Indole diterpenoids and isocoumarin from the fungus, Aspergillus flavus, isolated from the prawn, Penaeus vannamei. Mar. Drugs 2014, 12, 3970-3981. [CrossRef] [PubMed] 
18. Fan, Y.; Wang, Y.; Liu, P.; Fu, P.; Zhu, T.; Wang, W.; Zhu, W. Indole-diterpenoids with anti-H1N1 activity from the aciduric fungus Penicillium camemberti OUCMDZ-1492. J. Nat. Prod. 2013, 76, 1328-1336. [CrossRef] [PubMed]

19. Belofsky, G.N.; Gloer, J.B.; Wicklow, D.T.; Dowd, P.F. Antiinsectan alkaloids: Shearinines A-C and a new paxilline derivative from the ascostromata of Eupenicillium shearii. Tetrahedron 1995, 51, 3959-3968. [CrossRef]

20. Harms, H.; Rempel, V.; Kehraus, S.; Kaiser, M.; Hufendiek, P.; Müller, C.E.; König, G.M. Indoloditerpenes from a marine-derived fungal strain of Dichotomomyces cejpii with antagonistic activity at GPR18 and cannabinoid receptors. J. Nat. Prod. 2014, 77, 673-677. [CrossRef] [PubMed]

21. Yurchenko, A.N.; Ivanets, E.V.; Smetanina, O.F.; Pivkin, M.V.; Dyshlovoi, S.A.; von Amsberg, G.; Afiyatullov, S.S. Metabolites of the Marine Fungus Aspergillus candidus KMM 4676 Associated with a Kuril Colonial Ascidian. Chem. Nat. Compd. 2017, 53, 747-749. [CrossRef]

22. Sallam, A.A.; Houssen, W.E.; Gissendanner, C.R.; Orabi, K.Y.; Foudah, A.I.; El Sayed, K.A. Bioguided discovery and pharmacophore modeling of the mycotoxic indole diterpene alkaloids penitrems as breast cancer proliferation, migration, and invasion inhibitors. MedChem Comm 2013, 4. [CrossRef] [PubMed]

23. De Jesus, A.E.; Steyn, P.S.; van Heerden, F.R.; Vleggaar, R.; Wessels, P.L.; Hull, W.E. Tremorgenic mycotoxins from Penicillium crustosum. Structure elucidation and absolute configuration of penitrems B-F. J. Chem. Soc. Perkin Trans. 1 1983, 41, 1857-1861. [CrossRef]

24. De Jesus, A.E.; Steyn, P.S.; Van Heerden, F.R.; Vleggaar, R.; Wessels, P.L.; Hull, W.E. Tremorgenic mycotoxins from Penicillium crustosum: Isolation of penitrems A-F and the structure elucidation and absolute configuration of penitrem A. J. Chem. Soc. Perkin Trans. 1 1983, 14, 1847-1856. [CrossRef]

25. Penn, J.; Biddle, J.R.; Mantle, P.G.; Bilton, J.N.; Sheppard, R.N. Pennigritrem, a naturally-occurring penitrem A analogue with novel cyclisation in the diterpenoid moiety. J. Chem. Soc. Perkin Trans. 1 1992, 23, $23-26$. [CrossRef]

26. Cutler, H.G.; Cole, R.J.; Cox, R.H.; Wells, J.M. Fungal metabolites: Interesting new plant growth inhibitors. Proc. Plant Growth Regul. Work. Group 1979, 6, 87-91.

27. Cutler, H.G.; LeFiles, J.H.; Crumley, F.G.; Cox, R.H. Hydroxyterphenyllin: A novel fungal metabolite with plant growth inhibiting properties. J. Agric. Food Chem. 1978, 26, 632-635. [CrossRef]

28. Guo, Z.K.; Yan, T.; Guo, Y.; Song, Y.C.; Jiao, R.H.; Tan, R.X.; Ge, H.M. P-terphenyl and diterpenoid metabolites from endophytic Aspergillus sp. YXf3. J. Nat. Prod. 2012, 75, 15-21. [CrossRef] [PubMed]

29. Mantle, P.G.; Weedon, C.M. Biosynthesis and transformation of tremorgenic indole-diterpenoids by Penicillium paxilli and Acremonium lolii. Phytochemistry 1994, 36, 1209-1217. [CrossRef]

30. Dyshlovoy, S.A.; Menchinskaya, E.S.; Venz, S.; Rast, S.; Amann, K.; Hauschild, J.; Otte, K.; Kalinin, V.I.; Silchenko, A.S.; Avilov, S.A.; et al. The marine triterpene glycoside frondoside A exhibits activity in vitro and in vivo in prostate cancer. Int. J. Cancer 2016, 138, 2450-2465. [CrossRef] [PubMed]

31. Dyshlovoy, S.A.; Venz, S.; Shubina, L.K.; Fedorov, S.N.; Walther, R.; Jacobsen, C.; Stonik, V.A.; Bokemeyer, C.; Balabanov, S.; Honecker, F. Activity of aaptamine and two derivatives, demethyloxyaaptamine and isoaaptamine, in cisplatin-resistant germ cell cancer. J. Proteom. 2014, 96, 223-239. [CrossRef] [PubMed]

32. Dyshlovoy, S.A.; Hauschild, J.; Amann, K.; Tabakmakher, K.M.; Venz, S.; Walther, R.; Guzii, A.G.; Makarieva, T.N.; Shubina, L.K.; Fedorov, S.N.; et al. Marine alkaloid monanchocidin a overcomes drug resistance by induction of autophagy and lysosomal membrane permeabilization. Oncotarget 2015, 6, 17328-17341. [CrossRef] [PubMed]

(C) 2018 by the authors. Licensee MDPI, Basel, Switzerland. This article is an open access article distributed under the terms and conditions of the Creative Commons Attribution (CC BY) license (http:/ / creativecommons.org/licenses/by/4.0/). 